\title{
Legal Protection of Workers in Fostering Industrial Relations
}

DOI: https://doi.org/10.47175/rissj.v3i1.386

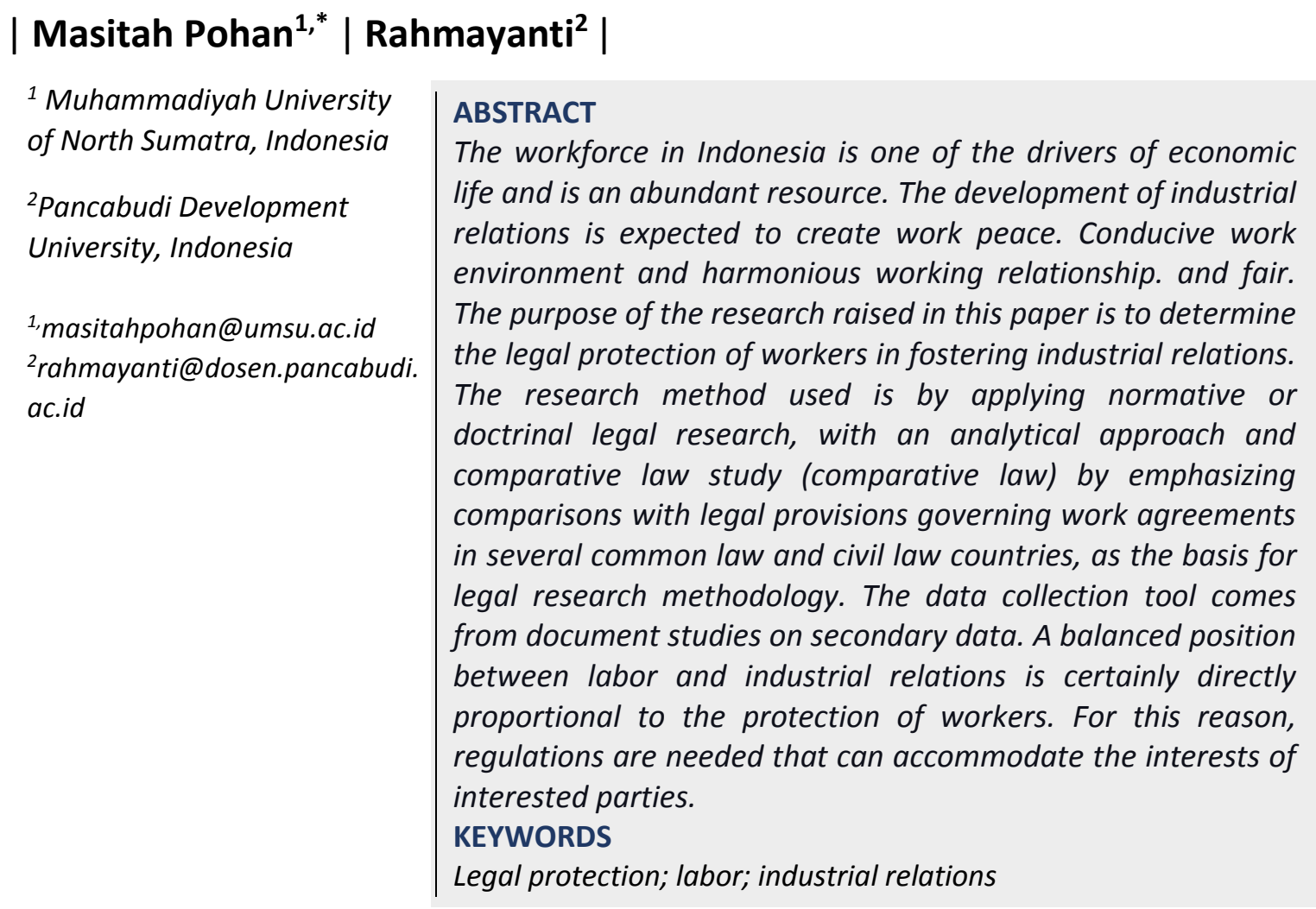

\section{INTRODUCTION}

Workers are improvement performing artists and financial on-screen characters both exclusively and in bunches, so they have a really noteworthy part in national financial exercises, to be specific expanding efficiency and open wellbeing. In Indonesia, the workforce in Indonesia is one of the drivers of economic life and may be a resource that's very plenteous in number. This sign can be seen within the still tall number of unemployed in Indonesia and the moo or negligible work openings given.

The definition of work law is profoundly subordinate on the positive laws of each nation. Subsequently, it isn't astounding that the definition of labor law (business) put forward by legal specialists is additionally different, particularly with respect to its breadth. This can be since the scope of labor law (labor) in each country is additionally diverse. In expansion, distinctive focuses of see too cause lawful specialists to supply distinctive definitions of labor law. In the following, several definitions of labor law (employment) by several experts will be presented. Labor law is broader than the previously known labor law whose scope only deals with the legal relationship between the worker and the employer in the employment relationship.

Support of relations between laborers, exchange unions and administration inside the scope of mechanical relations is exceptionally fundamental to anticipate clashes within the world of work. Clashes that are not quickly settled can lead to cases of mechanical relations debate due to disharmony between the individual parties. Clashes of intrigued between laborers in exchange unions and company administration happen due to contrasts in discernments and the fulfillment of clashing needs. Specialists in unions need tall welfare 
and wonderful working conditions, whereas company administration needs moo costs with tall benefits.

The framework of connections that happen between interrelated parties to attain the anticipated objectives within the generation handle is called mechanical relations (Swasto, 2011: 111). The smooth running of business within the generation prepare occurs when the parties within the company are successful in keeping up working relations within the mechanical circle. It is important to preserve working relations within the mechanical circle in overseeing laborers with distinctive characters, capacities and inspirations in working within the company. The maintenance of worker relations in the industrial sphere is carried out by the union as the representative of the workers and the management representing the company.

The definition of industrial relations is contained in Labor Law No. 13 Year 2003 Article 1 paragraph 16 which reads:

"Industrial Relations may be a system of relations shaped between on-screen characters within the prepare of creating merchandise and/or administrations comprising of components of business visionaries, workers/laborers, and the government based on the values of Pancasila and the 1945 Structure of the Republic of Indonesia."

To create harmonious industrial relations, employees have the function to complete their work in the company in accordance with their respective obligations. Employees also have a function to maintain order in the company and avoid conflicts. Employees can also express their opinions democratically and develop their skills to improve company performance. Meanwhile, a company has a function to establish good relationships with employees, develop their businesses, provide job opportunities for the community, and provide welfare for their employees. Companies should also as much as possible create harmonious industrial relations with employees. Companies must ensure that employee rights are met so that conflicts can be avoided.

Workers in the industrial sphere need to be nurtured through the development of industrial relations. The industrial relations are strived to be maintained in harmony through tolerance by respecting differences in achieving the same goal. Trade unions and management in maintaining worker relations must work together to create a conducive working climate through collective bargaining embodied in collective bargaining agreements that can serve as binding guidelines and benefit all parties. Industrial Relations can be defined as the efforts or steps of workers/labor unions/labor unions in conducting interactions either at the company or community level to fight for the terms and conditions of work. The objectives of Industrial Relations are: 1. Improving/increasing work requirements, economic conditions and social status of workers and their families, 2. Achieving industrial harmony through cooperation between employers and workers to ensure the welfare of workers and economic growth of companies and the state, 3. Participate in national decision-making processes through tripartite institutions. In the company, the position of the trade union is important because it ensures that the position and rights of workers can be balanced with the obligations that workers carry out for employers. Industrial Relations which will also discuss employment and the role of the government between rights and obligations between companies and workers/labor unions. Achieving industrial harmony through cooperation between employers and workers to ensure the welfare of workers and economic growth of companies and the state. 3 . Participate in national decision-making processes through tripartite institutions. In the company, the position of the trade union is important because it ensures that the position and rights of workers can be balanced with the obligations that workers carry out for employers. Industrial Relations which will also discuss employment and the role of the 
government between rights and obligations between companies and workers/labor unions. Achieving industrial harmony through cooperation between employers and workers to ensure the welfare of workers and economic growth of companies and the state. 3 . Participate in national decision-making processes through tripartite institutions. In the company, the position of the trade union is important because it ensures that the position and rights of workers can be balanced with the obligations that workers carry out for employers. Industrial Relations which will also discuss employment and the role of the government between rights and obligations between companies and workers/labor unions. The position of the trade union is important because it ensures that the position and rights of workers can be balanced with the obligations that workers carry out for employers. Industrial Relations which will also discuss employment and the role of the government between rights and obligations between companies and workers/labor unions. The position of the trade union is important because it ensures that the position and rights of workers can be balanced with the obligations that workers carry out for employers. Industrial Relations which will also discuss employment and the role of the government between rights and obligations between companies and workers/labor unions.

Where according to Law no. 13/2003 concerning Manpower Article 1 point 16, Industrial Relations could be a system of relations shaped between on-screen characters within the prepare of creating products and/or administrations comprising of components of business visionaries, workers/laborers, and the government based on the values of Pancasila and the Law the 1945 Constitution of the Republic of Indonesia. The most basic thing in the concept of industrial relations is the equal partnership between workers and employers, both of which havecommon interests, namely jointly wanting to improve the standard of living and develop the company (Koto and Hanifah, 2021). Besides that, the community also has an interest, both as a supplier of production factors, namely goods and services for the company's needs, as well as as a community.

With the above background, the researchers are interested in conducting research on how the implementation of industrial relations for workers, and how the legal protection of trade unions in industrial relations disputes.

\section{RESEARCH METHODS}

The research method utilized is by applying standardizing or doctrinal legitimate investigate, with an explanatory approach and comparative law ponder (comparative law) by emphasizing comparisons with lawful arrangements administering work understandings in a few common law and respectful law nations, as the premise for lawful inquire about strategy. The information collection strategy comes from report ponders on auxiliary information.

Secondary data includes primary legal materials, namely various laws and regulations that have a close relationship with labor in fostering industrial relations which analyzes: all data taken from laws and regulations relating to labor and industrial relations, various work agreement documents, court ruling. This research is prioritized on library materials, which include journals, books, dissertation summaries. The internet is also used in searching for library materials to find out the current situation and conditions that support this writing.

The procedure carried out in this research is by conducting interviews with informants, document studies, both in written and oral form with a comparative study approach. 


\section{RESULTS AND DISCUSSION \\ Implementation of Industrial Relations to Manpower}

Nowadays, the working relationship is a phenomenon that has attracted the attention of various parties in this country or world. We often hear about the problems of the workforce in our environment. Where this is also influenced by the work agreement. A work agreement according to Law No. 13 of 2003 is an agreement between a worker or laborer and a company or employer that contains the terms and conditions of the rights and obligations of the parties. The work agreement is basically made to prevent disputes or disputes that can occur between the parties involved in an employment relationship, namely the first party (the company) and the second party (employees).

According to Article 13/2003 number 16, Article 13/2003 of the law, industrial relations are labor-management relations referring to the system of relations formed between participants in the process of producing goods and/or services. Pancasila values of labor and government and the 1945 Constitution of the Republic of Indonesia. Labor disputes are due to disputes over rights, interests, dismissals, and union/labor union disputes that cause conflicts between employers or employers and workers. Company labor unions (Article 1 of Law Number 2 of 2004 concerning Settlement of Employment Relations).

Abdul Khakim (2009) explains that the term labor-management relationship is a translation of "labor-management relations" or work relations. The term which was initially assumed that the employment relationship only discussed the relationship between workers / workers and employers. In line with the development and realities of the site, the working relationship between workers/workers and employers involves many other aspects. Therefore, Abdul Khakim (2009) suggests that the labor-management relationship is not limited to the relationship between workers/labourers and employers, but also requires government intervention.

There are three elements that support the achievement of industrial relations goals, namely:

a) Rights and obligations guaranteed and implemented

b) If a dispute arises, it can be resolved internally / bipartite

c) Strikes by workers and lockouts by employers do not need to be used to impose their own will, because disputes that have occurred have been resolved properly.

However, the mental and social attitudes of entrepreneurs and workers are also very influential in achieving the success of our industrial relations goals. The mental and social attitudes that support the achievement of the industrial relations objectives are:

a) Treat workers as partners, and treat employers as investors

b) Willing to accept each other and improve the partnership relationship between employers and workers openly.

c) Respond to social conditions, wages, productivity and welfare of workers.

d) Develop a forum for communication, deliberation and kinship. Top of Form Bottom of Form

\section{Legal Protection Against Trade Unions in Industrial Relations Disputes}

Every worker, according to applicable law, has the same rights and opportunities. Including to establish or join a union in the company. Normatively, the definition of a trade union or labor union is an organization shaped from, by, and for workers/labor both interior and exterior the company, which is free, open, free, majority rule, and capable for battling for, protecting and securing the rights and interface of specialists/ laborers as well as progressing the welfare of laborers/ laborers and their families. 
The trade union itself has a goal that has been regulated by law, which is aimed at providing protection, defending rights and interests, as well as improving proper welfare for workers/laborers and their families.

In the company, the position of the trade union is important because it ensures that the position and rights of workers can be balanced with the obligations that workers carry out for employers.

Therefore, Trade Unions have certain rights, which include:

- The right to make a collective work agreement with the entrepreneur;

- The right to represent workers/laborers in resolving industrial disputes;

- The right to represent workers/ laborers in manpower institutions;

- The right to form institutions or carry out activities related to efforts to improve the welfare of workers/laborers. and;

- The right to carry out other activities in the field of manpower that do not conflict with the applicable laws and regulations.

Meanwhile, the obligations of a trade union/labor union are:

- Obliged to ensure and guard individuals from infringement of rights and battle for their interface;

- Obliged to fight for the improvement of the welfare of members and their families, and;

- Obliged to account for the organization's activities to its members in accordance with the articles of association and by-laws.

Laws related to manpower include Law No. 23 of 1948 concerning labor inspection, Law No. 21 of 1945 concerning Labor Agreements, and Law No. 22 of 1957 concerning Settlement of Labor Disputes, Law no. 1 of 2004 concerning the Settlement of Industrial Relations Disputes, and Law no. 3 of 2003 concerning Manpower.

Basically, tripartite negotiations are carried out by involving a third person through mediation, conciliation and arbitration or commonly referred to as the out-of-court or non-litigation stage. If the settlement of bipatriate and tripartite negotiations fails or the negotiations do not reach an agreement, then the industrial relations dispute case can be carried out through the industrial relations court (PHI) or through litigation (Mulyadi. L, 2011).

\section{CONCLUSION}

Conducive industrial relations between entrepreneurs and workers/labourers are the main key to avoid this happening Work termination, aims to put workers in a proportional state.

Legal protection for trade unions in relational disputes aims to achieve industrial relations from industrial relations, namely the creation of a condition of industrial peace or a condition of mutual welfare between workers and employers.

\section{Suggestion}

Workers and employers must understand each other and carry out their respective rights and obligations, because the relationship between workers and employers is an enhanced relationship.

\section{REFERENCES}

Abdul Kadir Muhammad. (2010). Hukum Perusahaan Indonesia, Bandung: Citra Aditya Bakti

Budiono, Abdul R. (2009). Hukum Perburuhan. Jakarta: PT. Indeks Code of Civil law Daft, Richard L. (2012). Era Baru Manajemen. Jakarta: Salemba Empat 
Dr. Lilik Mulyadi, S.H., M.H., Agus Subroto, S.H., M.Hum. (2011). Penyelesaian Perkara Pengadilan Hubungan Indusrtial dalam Teori Dan Praktik, Bandung: PT.Alumni

Gunarto. (2010). Rekonstruksi konsep kebebasan hak berserikat bagi serikat pekerja pada hubungan industrial berbasis nilai keadilan. JurnalDinamika Hukum, 10(3)

Koto, I., \& Hanifah, I. (2021). The Legal Protection for Female Workers in the Perspective of Islamic Law and Law No. 11 Year 2020 on Job Creation. Randwick International of Social Science Journal, 2(4), 524-534. https://doi.org/10.47175/rissj.v2i4.333

Lalu Husni. (2000). Pengantar Hukum Ketenagakerjaan, Jakarta: Rajawali Perss

Law No. 2 of 2004 concerning Settlement of Industrial Relations

Law No. 13 of 2003 concerning Employment

Sutedi, Adrian. (2009). Hukum Perburuhan. Jakarta: Sinar Grafika

Rumimpunu, Fritje. (2014). Sistem hubungan industrial pancasila di Indonesia dengan tenaga kerja, perusahaan seen from the aspect (Labor Law No. 13 Year 2003). Jurnal Hukum Unsrat, 2(2) 